\title{
Growth Performance, Haematological Indices and Some Biochemical Enzymes of Juveniles Clarias gariepinus (Burchell 1822) Fed Varying Levels of Moringa oleifera Leaf Meal Diet
}

\section{Bello Nuhu Ozovehe*}

University of Ilorin, Ilorin, kwara, Nigeria

\begin{abstract}
The study examined the utilization, hematological and biochemical enzymes of Clarias gariepinus juveniles fed varying levels of Moringa oleifera leaf meal diets for a period of 8 weeks. Moringa oleifera leaf meal substituted fish meal at $0 \%$ (control), $10 \%, 20 \%, 30 \%, 40 \%$ and $50 \%$ in the six different diets. Clarias gariepinus juveniles (mean weight $29.69 \pm 0.91 \mathrm{~g}$ ) were randomly distributed into 18 concrete tanks at 10 fish/tank in triplicate treatments and were fed twice daily at 8.00 hrs -9.00 hrs and 17.00 hrs- 18.00 hrs for 8 weeks. The mean weight gained (MWG), specific growth rate (SGR), feed conversion ratio (FCR), protein efficiency ratio (PER) were calculated. The results obtained in the experiment showed that fishes fed with the control diet did not show statistical significant $(p>0.05)$ difference from fishes fed with $10 \%$ and $20 \%$ M. oleifera leaf meal diet in mean weight gain (MWG), specific growth rate (SGR) and feed conversion ratio (FCR). The haematological parameters results showed that the mean values of packed cell volume (PCV), red blood cell $(\mathrm{RBC})$ and haemoglobin $(\mathrm{Hb})$ were $27.17 \pm 1.94 \%, 2.33 \pm 0.38 \times 10^{6} \mathrm{~mm}^{-3}$ and $8.06 \pm 0.54 \mathrm{~g} / 100 \mathrm{ml}$ respectively in the fishes in the experiment. These parameters decreased as $M$. oleifera leaf meal increased in the diet. The serum enzymes: Alanine aminotransferase (ALT), Aspartate aminotransferase (AST) and Alkaline phosphatase (ALP), in the fishes fed with diet containing $0 \%, 10 \%$ and $20 \% \mathrm{M}$. oleifera leaf meal were not statistically significant $(p>0.05)$. The present study showed that $M$. oleifera leaf meal has good potential for use as fish meal substitute in $C$. gariepinus diet up to $10 \%$ level without compromising growth. The toxicological investigation indicated that at above $20 \%$ M. oleifera leaf meal in the diet, the serum enzymes increased suggesting cellular damage.
\end{abstract}

\section{Introduction}

Fish culture is the fastest growing sector of the world's animal production with an annual increase of about $10 \%$ [1]. To sustain such high rates of increase in production, a matching increase in fish feed production is imperative. The high cost and fluctuating quality as well as the uncertain availability of fish meal have led to the need to identify alternative protein sources for fish feed formulation. Therefore, in order to attain more economically, sustainable, environmentally friendly and viable production, research interest has been directed towards the evaluation and use of non-conventional sources of plant protein.

Forage trees such as Leucaena leucocephala (Lam de Wit) demonstrated good potential to serve as a useful plant source in fish ration and in the livestock industry generally [2-4]. However, it has been established that leucaena contains mimosine-a non-protein amino acid capable of inhibiting protein biosynthesis in animal causing growth retardation if consumed intensively $[3,4]$.

Similarly, many of these forage trees have not been widely used because they often contain antinutritional compounds that have deleterious effects on animal yield $[5,6]$.

Many studies have also, been conducted using various sources of leaf meal proteins $\mathrm{Ng}$ and Wee [7], on cassava leaf meal, Yousif et al. [8] on Alfalfa and Reyes and Fermin [9], on Carica papaya and other leaf meal such as the sweet potato Ipomoea batatas L. have also been worked on by several researchers. Leaf meal has a high protein content of between 26 to $33 \%$ with high amino acid score and good mineral profile and vitamins such as $A_{1}, B_{2}, C$ and $E$ [10-12].

Recently, researchers have increasingly been paying attention to moringa (Moringa oleifera Lam.). It belongs to the moringaceae family, and is considered to have its origin in the north-west region of India. Moringa oleifera can have a total dry matter (DM) yield up to 24 ton ha-
${ }^{1}$ year $^{-1}[13]$ and has a crude protein (CP) content in fresh leaves varying from 193 to $246 \mathrm{~g} \mathrm{~kg}^{-1} \mathrm{DM}$. Moringa fresh foliage has been included into the diet of different animals, positive effects on feeding behaviour in goat [14, growth rate in sheep [15] and milk yield in dual purpose cows [16] have been reported. Moringa can also be dried and used in the form of Moringa Leaf meal (MLM), 30\% substitution of Moringa oleifera leaf meal for fish meal has been recommended for the diet of Nile tilapia Oreochromis niloticus [17] and cross-bred dairy cows [18].

The literature reviewed showed that no work has been reported on the effects of Moringa oleifera leaf meal in the diet of Clarias gariepinus. The aim of this research therefore, is to determine the ability of Moringa oleifera leaf meal to serve as source of protein in formulated diets of Clarias gariepinus and also to assess it effects on haematological and biochemical enzymes.

\section{Materials and Methods}

\section{Experimental site}

The research was conducted at Ministry of Agriculture and Natural

*Corresponding author: Bello Nuhu Ozovehe, University of Ilorin, Ilorin, kwara, Nigeria; E-mail: bellonuhu07@yahoo.com

Received November 06, 2012; Accepted November 27, 2012; Published December 07, 2012

Citation: Ozovehe BN (2013) Growth Performance, Haematological Indices and Some Biochemical Enzymes of Juveniles Clarias gariepinus (Burchell 1822) Fed Varying Levels of Moringa oleifera Leaf Meal Diet. J Aquac Res Development 4:166 doi:10.4172/2155-9546.1000166

Copyright: (c) 2013 Ozovehe BN. This is an open-access article distributed under the terms of the Creative Commons Attribution License, which permits unrestricted use, distribution, and reproduction in any medium, provided the original author and source are credited. 
Citation: Ozovehe BN (2013) Growth Performance, Haematological Indices and Some Biochemical Enzymes of Juveniles Clarias gariepinus (Burchell 1822) Fed Varying Levels of Moringa oleifera Leaf Meal Diet. J Aquac Res Development 4:166 doi:10.4172/2155-9546.1000166

Page 2 of 6

Resources Ilorin, in eighteen (18) rectangular concrete tanks for a period of eight (8) weeks from January to February 2012.

\section{Moringa oleifera leaf processing}

Moringa leaves (Moringa oleifera Lam.) were collected from a moringa farm in Alliero community, Kebbi State, Nigeria and were authenticated in the Herbarium of the Plant Biology Department University of Ilorin. The leaves were thoroughly washed with water to remove dirt, drained properly and later shade dried for seven days. Thereafter, the leaves were ground into fine powder and analyzed for proximate composition according to AOAC [19]. The parameters of importance were crude protein, crude fat, crude fiber, moisture content and total ash.

\section{Fish diet formulation and processing}

Six different diets were prepared using Pearson's method of fish feed formulation to contain $40 \%$ crude protein. The Moringa oleifera Leaf Meal (MLM) was incorporate into each of the diet at $0 \%$ (control), $10 \%$, $20 \%, 30 \%, 40 \%$ and $50 \%$ to replace equal weight of fish meal.

Prior to processing, the feed ingredients were ground individually to a fine powder by using harmer mill machine, then individually weighed and properly mixed together with adequate water added to ensure smooth pelleting. The strands were cut into short pieces and sun dried for 3 days to remove moisture [20]. Samples of the experimental diets were subjected to proximate analyses. All analyses followed the procedures of (AOAC 2000) [19].

\section{Experimental design and feeding trials}

One hundred and eighty (180) African catfish juveniles (Clarias gariepinus) of average weight $29.69 \pm 0.91$ g were purchased from Kwara State Ministry of Agriculture production farm, Ilorin, Nigeria. The fish were allowed to acclimatize for 3 days [21] and were fed on commercial diet, prior to the commencement of the experiment; all fish were starved for 24 hours. This practice was to eliminate variation in weight due to residue food in the gut and also to prepare the gastrointestinal tract for the experimental diets, while at the same time to increase the appetite of the fish. The fish initial weight ranged from 20.00-39.36 g, mean weight $29.69 \mathrm{~g}$ were weighed with mettler top loading balance. The initial mean standard length $(10.50 \mathrm{~cm})$ and initial mean total length $(11.50$ $\mathrm{cm})$ were measured with graduated rule and recorded. The 18 concrete tanks were randomly allocated to six treatment diets (A.B,C,D,E and F) in triplicate and fish were randomly distributed into the tanks at a stocking density of ten fingerlings per tank. Feedings were generally carried out twice daily, (8.00 hrs-9.00 hrs) and (17.00 hrs-18.00 hrs). Subsequently, total weight and standard length measurements were taken fortnightly. The experimental fish at the beginning and the end of the feeding trial were subjected to proximate analysis. All analysis followed the procedures of AOAC [19].

The growth parameters were calculated following the method described by Bagenal [22].

\section{Protein efficiency ratio (PER)}

$$
\text { PER }=\frac{\text { Wet weight gain }(g)}{\text { Crude protein fed }}
$$

Specific growth rate (SGR)

$$
\mathbf{S G R}=\frac{\log \left(w t_{2}\right)-\log \left(w t_{1}\right)}{t_{2}-t_{1}} \times \frac{100}{1}
$$

$\log \left(\mathrm{wt}_{1}\right)=$ natural $\log$ of the weight of animal at the initial stage $(\mathrm{t} 1)$

$\log \left(w t_{2}\right)=$ natural log of the weight of animal at the final stage ( $\left.t 2\right)$.

Feed conversion ratio (FCR)

$\mathrm{FCR}=\frac{\text { Mass of food consumed dry }}{\text { Increase in mass of animal produced wet }} \times \frac{100}{1}$

Mean weight gain (MWG)

MWG=(W.Sub. 2) $-($ W.Sub. 1).

(W. Sub. 2)=Initial weight (g) of fish.

(W. Sub. 1)=Final weight (g) of fish.

Protein intake (PI)

PI=Feed fed $\mathrm{x}$ Fraction of the crude protein of the feed.

Condition factor $(\mathrm{K})$

$K=\frac{100 W}{L^{3}}$

$\mathrm{W}=$ Final mean body weight $(\mathrm{g})$

$\mathrm{L}=$ Mean standard length $(\mathrm{cm})$

Survival rate (SR)

$$
\frac{\text { Initial number of fish stocked }- \text { mortality }}{\text { Initial number of fish }} \times \frac{100}{1}
$$

\section{Water quality parameters}

Water quality parameters were measured fortnightly. Temperature was measured using mercury in glass thermometer, was measured by Jenway pH meter (Model E 512) and dissolved oxygen was determined by the method of APHA [23].

\section{Blood collection and haematological analysis}

Blood samples were collected at the beginning and $8^{\text {th }}$ week of the experiment respectively. Blood samples were collected following the procedure of Klontz and Smith [24] and Wedemeyer and Yasutake [25]. Blood samples were collected in triplicate into sample bottles containing Ethylene diamine tetraacetic acid (EDTA) as anticoagulant to give a concentration of $5 \mathrm{mg} / \mathrm{ml}$ of blood sampled. The blood sample was rocked gently in the bottle to allow thorough mixing of its contents. Thereafter, the samples were taken to the department of Haematology,

\begin{tabular}{|l|l|l|l|l|l|l|}
\hline Ingredients & A Control & B & C & D & E & F \\
\hline MLM & 0.00 & 3.00 & 6.00 & 9.00 & 12.00 & 15.00 \\
\hline Fish meal & 30.00 & 27.00 & 24.00 & 21.00 & 18.00 & 15.00 \\
\hline Soyabeans (toasted) & 19.00 & 19.00 & 19.00 & 19.00 & 19.00 & 19.00 \\
\hline Groundnut cake & 20.00 & 20.00 & 20.00 & 20.00 & 20.00 & 20.00 \\
\hline Maize & 29.00 & 29.00 & 29.00 & 29.00 & 29.00 & 29.00 \\
\hline D.C.P. & 1.00 & 1.00 & 1.00 & 1.00 & 1.00 & 1.00 \\
\hline Vitamin premix & 0.5 .00 & 0.5 .00 & 0.5 .00 & 0.5 .00 & 0.5 .00 & 0.5 .00 \\
\hline Lysine & 0.3 .00 & 0.3 .00 & 0.3 .00 & 0.3 .00 & 0.3 .00 & 0.3 .00 \\
\hline Methionine & 0.2 .00 & 0.2 .00 & 0.2 .00 & 0.2 .00 & 0.2 .00 & 0.2 .00 \\
\hline Moisture content (\%) & 9.85 & 7.31 & 8.06 & 8.12 & 7.97 & 8.10 \\
\hline Crude fibre (\%) & 5.05 & 5.03 & 4.74 & 4.61 & 4.47 & 4.15 \\
\hline Crude protein (\%) & 40.65 & 40.81 & 39.25 & 39.02 & 39.50 & 39.25 \\
\hline Crude fibre (\%) & 3.97 & 5.36 & 6.25 & 6.97 & 7.21 & 7.85 \\
\hline Total ash (\%) & 4.97 & 4.84 & 5.05 & 5.37 & 5.70 & 5.82 \\
\hline NFE & 35.31 & 36.65 & 36.65 & 35.91 & 35.15 & 34.83 \\
\hline
\end{tabular}

Table 1: Percentage composition (\%) of the Experimental diets. 
Citation: Ozovehe BN (2013) Growth Performance, Haematological Indices and Some Biochemical Enzymes of Juveniles Clarias gariepinus (Burchell 1822) Fed Varying Levels of Moringa oleifera Leaf Meal Diet. J Aquac Res Development 4:166 doi:10.4172/2155-9546.1000166

Page 3 of 6

University of Ilorin Teaching Hospital (UITH) for haematological analysis.

\section{Serum collection and biochemical analysis}

Blood samples were collected in triplicate at the beginning and $8^{\text {th }}$ week of the experiment respectively following the procedure of Klontz and Smith; Wedemeyer and Yasutake [24,25]. The blood was collected in sterile plastic test tubes without anticoagulant. The tubes were kept in a slanting wooding rack at room temperature to allow the blood to clot. The clotted blood was centrifuged for 15 minutes at 3500 revolution per minute (rpm). A clear fluid which is the serum was pipetted out into a clean and sterilized bottle for further analysis [26].

Alkaline phosphatase (ALP) activity was performed using the modified method of Wright et al. [27], Aspartate aminotranferase (AST) and Alanine aminotransferase (ALT) activities were carried out according to the methods described by Reitman and Frankel [28].

\section{Statistical analysis}

All data collected were subjected to analysis of variance (ANOVA). Comparisons among diets means were carried out by Duncan Multiple Range Test [29] at a significant level of 0.05. All computation was performed using statistical package SPSS 15.0 (SPSS Inc., Chicago, IL, U.S.A.).

\begin{tabular}{|l|l|l|l|}
\hline Proximate Composition (\%) & Initial & A & B \\
\hline Moisture content & $6.35^{\mathrm{c}} \pm 0.35$ & $8.34^{\mathrm{a}} \pm 0.02$ & $7.27^{\mathrm{b}} \pm 018$ \\
\hline Crude lipid & $5.20^{\mathrm{d}} \pm 0.20$ & $6.13^{\mathrm{a}} \pm 0.10$ & $6.05^{\mathrm{a}} \pm 0.30$ \\
\hline Crude protein & $59.40^{\mathrm{d}} \pm 0.40$ & $63.27^{\mathrm{a}} \pm 0.30$ & $62.39^{\mathrm{b}} \pm 0.45$ \\
\hline Crude fibre & - & $0.03^{\mathrm{c}} \pm 0.00$ & $0.03^{\mathrm{c}} \pm 0.00$ \\
\hline Total ash & $5.50^{\mathrm{c}} \pm 1.00$ & $6.05 \mathrm{~b}^{\mathrm{c}} \pm 0.02$ & $6.39^{\mathrm{ab}} \pm 0.04$ \\
\hline NFE & 23.55 & 16.18 & 17.87 \\
\hline
\end{tabular}

Figures on the same row having the same superscript are not significantly different $(p>0.05)$

\section{Results}

Table 1 shows the percentage composition of the various ingredients used in the feed formulation of the experimental diets. Treatment A contained $0 \%$ Moringa oleifera leaf meal and treatment B, C, D, E and $\mathrm{F}$ contained $10 \%, 20 \%, 30 \%, 40 \%$ and $50 \%$ M. oleifera leaf meal respectively.

The crude protein content of the diet ranged between 39.02 and $40.81 \%$, crude lipid 4.15 and $5.05 \%$ and crude fibre 3.97 and $7.85 \%$.

Table 2 shows the proximate composition of the fish carcass fed $M$. oleifera leaf meal based diet in the experiment. The highest protein value of $63.27 \%$ was recorded in fishes fed control diet and the lowest value of $60.20 \%$ was obtained in fishes fed $50 \%$ M. oleifera leaf meal diet. Carcass lipid also showed an increase in all the treatments with fishes fed $10 \%$ M. oleifera leaf meal diet recording the highest value of $6.13 \%$ and the lowest value of $5.50 \%$ was recorded in fishes fed $40 \% \mathrm{M}$. oleifera leaf meal diet.

The results for the feed utilization and growth parameters are presented in table 3. Fishes fed the control diet gained $21.69 \mathrm{~g}$, while the fishes fed $10 \% \mathrm{M}$ oleifera leaf meal diet gained $21.03 \mathrm{~g}$ and $20.53 \mathrm{~g}$ weight gain was recorded in fishes fed diet containing $20 \% \mathrm{M}$. oleifera leaf meal. The fishes fed control diet, $10 \%$ and $20 \%$ M. oleifera leaf meal

\begin{tabular}{|l|l|l|l|} 
C & D & E & F \\
\hline $7.30^{b} \pm 0.30$ & $7.03^{\mathrm{bc}} \pm 0.24$ & $7.00 b^{\mathrm{c}} \pm 1.00$ & $7.02 \mathrm{~b}^{\mathrm{c}} \pm 0.33$ \\
\hline $5.80^{\mathrm{b}} \pm 0.20$ & $5.74^{\mathrm{b}} \pm 0.10$ & $5.50^{\mathrm{c}} \pm 0.15$ & $5.60^{\mathrm{c}} \pm 0.26$ \\
\hline $60.98^{\mathrm{c}} \pm 0.21$ & $60.31^{\mathrm{c}} \pm 0.60$ & $60.29^{\mathrm{c}} \pm 0.20$ & $60.20^{\mathrm{c}} \pm 0.25$ \\
\hline $0.04^{\mathrm{bc}} \pm 0.01$ & $0.05^{\mathrm{b}} \pm 0.01$ & $0.06^{\mathrm{b}} \pm 0.01$ & $0.08^{\mathrm{a}} \pm 0.01$ \\
\hline $6.54^{\mathrm{ab}} \pm 0.20$ & $6.60^{\mathrm{ab}} \pm 0.10$ & $6.74^{\mathrm{ab}} \pm 0.23$ & $6.95^{\mathrm{a}} \pm 0.25$ \\
\hline 19.34 & 20.27 & 20.27 & 20.26
\end{tabular}

Table 2: Proximate composition (\%) of Clarias gariepinus carcass fed Moringa oleifera based diet.

\begin{tabular}{|c|c|c|c|c|c|c|}
\hline Parameters & A & B & C & D & E & $\mathbf{F}$ \\
\hline Initial mean weight (g) & $39.00^{\mathrm{a}} \pm 0.53$ & $39.36^{a} \pm 0.64$ & $35.57^{b} \pm 0.07$ & $24.17^{c} \pm 0.17$ & $20.04^{d} \pm 0.54$ & $20.00^{d} \pm 3.50$ \\
\hline Mean final weight gain (g) & $60.69^{a} \pm 0.17$ & $60.39^{a} \pm 0.34$ & $56.10^{b} \pm 0.79$ & $34.45^{c} \pm 2.18$ & $29.40^{d} \pm 0.87$ & $28.85^{d} \pm 0.52$ \\
\hline Mean weight gained (g) & $21.69^{a} \pm 1.68$ & $21.03^{a} \pm 0.04$ & $20.53^{\mathrm{a}} \pm 0.13$ & $10.28^{b} \pm 0.48$ & $9.36^{c} \pm 0.06$ & $8.85^{d} \pm 0.05$ \\
\hline Mean daily weight. gain (g) & $0.39^{\mathrm{a}} \pm 0.02$ & $0.38^{a} \pm 0.02$ & $0.37^{a} \pm 0.05$ & $0.18^{b} \pm 0.04$ & $0.17^{b} \pm 0.01$ & $0.16^{a} \pm 0.02$ \\
\hline Feed intake $(\mathrm{g}) /$ fish & $41.35^{a} \pm 1.30$ & $41.20^{a} \pm 0.05$ & $41.01^{\mathrm{a}} \pm 1.02$ & $37.62^{\mathrm{b}} \pm 0.02$ & $38.02^{b} \pm 0.05$ & $38.35^{b} \pm 0.05$ \\
\hline Specific growth rate (SGR) & $0.34^{a} \pm 0.02$ & $0.33^{a} \pm 0.01$ & $0.35^{a} \pm 0.02$ & $0.27^{c} \pm 0.02$ & $0.30^{\mathrm{b}} \pm 0.02$ & $0.28^{c} \pm 0.02$ \\
\hline Food conversion ratio (FCR) & $1.91^{\mathrm{cd}} \pm 0.02$ & $1.96^{\mathrm{cd}} \pm 0.25$ & $2.00^{c} \pm 0.05$ & $3.66^{b c} \pm 0.01$ & $4.06^{b} \pm 0.07$ & $4.33^{a} \pm 0.03$ \\
\hline Protein efficiency ratio (PER) & $1.31^{\mathrm{a}} \pm 0.04$ & $1.28^{\mathrm{a}} \pm 0.05$ & $1.25^{\mathrm{a}} \pm 0.06$ & $0.68^{\mathrm{b}} \pm 0.03$ & $0.62^{\mathrm{bc}} \pm 0.02$ & $0.58^{c} \pm 0.02$ \\
\hline Protein intake (PI) & $16.54^{\mathrm{a}} \pm 1.04$ & $16.48^{a} \pm 0.20$ & $16.40^{\mathrm{a}} \pm 0.44$ & $15.05^{b} \pm 0.88$ & $15.21^{b} \pm 0.33$ & $15.34^{b} \pm 0.44$ \\
\hline Standard length (SL) & $15.50^{\mathrm{a}} \pm 1.00$ & $15.00^{a} \pm 0.50$ & $14.50^{\mathrm{a}} \pm 0.75$ & $12.50^{b} \pm 0.050$ & $10.50^{c} \pm 0.33$ & $10.00^{c} \pm 0.50$ \\
\hline Condition factor (K) & $1.63^{c} \pm 0.15$ & $1.64^{c} \pm 0.13$ & $2.01^{b} \pm 0.15$ & $1.76^{\mathrm{bc}} \pm 0.10$ & $2.75^{\mathrm{a}} \pm 0.40$ & $2.70^{\mathrm{a}} \pm 0.25$ \\
\hline Survival rate (SR) (\%) & 96.67 & 93.33 & 90 & 96.67 & 93.33 & 90 \\
\hline
\end{tabular}

Figures on the same row having the same superscript are not significantly different $(p>0.05)$

Table 3: Growth response, nutrient utilization and survival parameters of Clarias gariepinus juvenile fed different levels of Moringa oleifera leaf meal diet.

\begin{tabular}{|c|c|c|c|c|c|c|c|}
\hline Blood Parameters & Initial & A & B & C & D & E & $\mathbf{F}$ \\
\hline PCV (\%) & $27.80^{\mathrm{b}} \pm 1.00$ & $32.00^{\mathrm{a}} \pm 2.00$ & $30.00^{\mathrm{a}} \pm 1.00$ & $27.00^{\mathrm{b}} \pm 2.00$ & $26.00^{c} \pm 2.00$ & $24.00^{c} \pm 2.65$ & $24.00^{c} \pm 2.00$ \\
\hline WBC $\left(10^{3} \mathrm{~mm}^{-3}\right)$ & $7.20^{\circ} \pm 0.50$ & $7.45^{\mathrm{bc}} \pm 0.20$ & $7.50^{\mathrm{bc}} \pm 0.20$ & $7.60^{\mathrm{b}} \pm 0.20$ & $7.60^{b} \pm 0.20$ & $8.00^{a} \pm 0.25$ & $8.02^{\mathrm{a}} \pm 0.33$ \\
\hline $\operatorname{RBC}\left(10^{6} \mathrm{~mm}^{-3}\right)$ & $2.80^{b} \pm 0.02$ & $3.60^{\mathrm{a}} \pm 0.20$ & $3.20^{\mathrm{a}} \pm 0.50$ & $2.00^{b} \pm 0.20$ & $1.90^{\mathrm{b}} \pm 0.10$ & $1.80^{b} \pm 0.29$ & $1.50^{\mathrm{bc}} \pm 1.00$ \\
\hline $\mathrm{Hb}(\mathrm{g} / 100 \mathrm{ml})$ & $8.00^{b} \pm 0.50$ & $9.20^{\mathrm{a}} \pm .0 .40$ & $9.00^{\mathrm{a}} \pm 0.10$ & $8.10^{b} \pm 0.24$ & $8.00^{b} \pm 1.01$ & $7.00^{c} \pm 0.50$ & $7.05^{c} \pm 1.00$ \\
\hline LYMPH (\%) & $60.00^{c} \pm 10.00$ & $63.00^{b} \pm 2.00$ & $63.02^{\mathrm{a}} \pm 2.00$ & $65.00^{\mathrm{a}} \pm 2.00$ & $69.00^{\mathrm{b}} \pm 1.00$ & $70.00^{\mathrm{a}} \pm 2.00$ & $70.00^{a} \pm 2.00$ \\
\hline $\mathrm{MCHC}(\%)$ & $28.78^{\mathrm{ab}} \pm 2.03$ & $28.75^{\mathrm{ab}} \pm 1.0$ & $30.00^{a} \pm 2.00$ & $30.00^{\mathrm{a}} \pm 0.47$ & $30.77^{\mathrm{a}} \pm 1.00$ & $29.17^{a} \pm 0.60$ & $29.38^{a} \pm 2.00$ \\
\hline $\mathrm{MCH}(\mathrm{pg})$ & $28.57^{\mathrm{cd}} \pm 0.50$ & $25.56^{d} \pm 1.43$ & $28.13^{\text {cd }} \pm 0.30$ & $40.50^{\mathrm{b}} \pm 2.60$ & $42.11^{\mathrm{b}} \pm 0.42$ & $36.84^{c} \pm 0.60$ & $47.00^{\mathrm{a}} \pm 3.29$ \\
\hline $\operatorname{MCV}(f l)$ & $100.00^{c} \pm 2.00$ & $88.89^{d} \pm 2.08$ & $93.75^{d} \pm 1.53$ & $135.00^{b} \pm 3.09$ & $136.84^{b} \pm 1.00$ & $133.33^{b} \pm 0.40$ & $160.00^{\mathrm{a}} \pm 10.00$ \\
\hline
\end{tabular}

Figures on the same row having the same superscript are not significantly different $(p>0.05)$

Table 4: Haematological parameters of Clarias gariepinus juveniles fed different levels of Moringa oleifera leaf meal diet. 
Citation: Ozovehe BN (2013) Growth Performance, Haematological Indices and Some Biochemical Enzymes of Juveniles Clarias gariepinus (Burchell 1822) Fed Varying Levels of Moringa oleifera Leaf Meal Diet. J Aquac Res Development 4:166 doi:10.4172/2155-9546.1000166

diet did not show statistical significant $(\mathrm{p}>0.05)$ difference but were significantly different $(\mathrm{p}<0.05)$ from values obtained in fishes fed diet containing $30 \%, 40 \%$ and $50 \%$ M. oleifera leaf meal.

The results for the specific growth rate (SGR) showed that fishes fed with $20 \%$ M. oleifera leaf meal diet had the highest value of 0.35 and lowest value of 0.27 was recorded in fishes fed with $30 \%$ M. oleifera leaf meal diet. The specific growth rate (SGR), mean weight gain (MWG) and protein efficiency ratio (PER) showed a negative correlation with increase in $M$. oleifera leaf meal in the diet with values $-0.69,-0.91$ and -0.92 respectively.

There was no significant difference $(p>0.05)$ in the feed conversion ratio (FCR) in fishes fed the control diet and $10 \%$ M. oleifera leaf meal diet.

The highest value of 1.31 recorded for protein efficiency ratio (PER) was observed in fishes fed control diet and the lowest value of 0.58 was recorded in fishes fed diet containing 50\% M. oleifera leaf meal diet.

The protein intake values of $16.54,16.48$ and 16.40 were obtained in fishes fed control diet, $10 \%$ and $20 \%$ M. oleifera leaf meal based diet respectively. These values did not show significant $(\mathrm{p}>0.05)$ difference but were significantly different $(\mathrm{p}<0.05)$ when compared with fishes that were fed with $30 \%, 40 \%$ and $50 \% \mathrm{M}$. oleifera leaf meal diet.

Fish growth exhibited significant inverse correlation with condition factor $(\mathrm{K})$. The correlation coefficient (r) was recorded as -0.85 .

Table 4 revealed the haematological indices of fishes fed Moringa oleifera leaf meal based diet during the experiment. The Packed cell volume (PCV) results showed that fishes fed diet containing $0 \%$ and $10 \%$ M. oleifera leaf meal had values of $32.00 \%$ and $30.00 \%$ respectively. These values were not statistically significant $(p>0.05)$. The fishes fed diet containing $20 \%$ to $50 \%$ M. oleifera leaf meal diet showed a decrease in the PCV.

White blood cells result showed that fishes fed $20 \%$ to $50 \% \mathrm{M}$. oleifera leaf meal diet had higher values than fishes fed control and 10\% $M$. oleifera leaf meal diet. The highest value of $8.20 \times 103 \mathrm{~mm}-3$ was recorded in fishes fed diet containing 50\% M. oleifera leaf meal, which was not statistically significant $(\mathrm{P}>0.05)$ from fishes fed diet containing $40 \%$ M. oleifera leaf meal.

The red blood cell (RBC) showed a decrease as M. oleifera leaf meal increased in the diet. The fishes fed control diet and $10 \% \mathrm{M}$. oleifera leaf meal diet recorded values of $3.60 \times 10^{3} \mathrm{~mm}^{-3}$ and $3.20 \times 10^{3} \mathrm{~mm}^{-3}$ respectively and were not significantly different $(\mathrm{P}>0.05)$ but were significantly different from fishes fed diet containing $20 \%$ to $50 \% \mathrm{M}$. oleifera leaf meal.

Haemoglobin decreased in fishes fed diet containing 20\% to 50\% M. oleifera leaf meal. The fishes fed control diet and $10 \%$ M. oleifera leaf meal diet recorded values of $9.20 \mathrm{~g} / 100 \mathrm{ml}$ and $9.00 \mathrm{~g} / 100 \mathrm{ml}$ respectively. These values showed a significant $(\mathrm{P}>0.05)$ difference from fishes fed diet containing $20 \%$ to $50 \%$ M. oleifera leaf meal.

Lymphocyte count showed an increase as the level of M. oleifera leaf meal increased in the diet. The highest value of $70.00 \%$ was jointly recorded in fish fed diet containing 40\% and 50\% M. oleifera leaf meal diet and the least value of $63.00 \%$ was recorded in fish fed the control diet.

The highest value of $30.77 \%$ for $\mathrm{MCHC}$ was recorded in fish fed diet containing 30\% M. oleifera leaf meal diet and the lowest value of $28.75 \%$ was obtained in fish fed control diet.

The results obtained for $\mathrm{MCH}$ and MCV showed that the fishes fed diet containing $50 \% \mathrm{M}$. oleifera leaf meal had the highest values of 47.00 pg and $160.00 \mathrm{fl}$ for $\mathrm{MCH}$ and $\mathrm{MCV}$ respectively and the least values of $25.56 \mathrm{pg}$ and $88.89 \mathrm{fl}$ were recorded for $\mathrm{MCH}$ and MCV in fish fed control diet.

The PCV, RBC and $\mathrm{Hb}$ showed a significant $(\mathrm{P}<0.01)$ inverse correlation with increase in $M$. oleifera leaf meal in the diet. The correlation coefficient $(r)$ of $-0.70,-0.92$ and -0.65 were recorded for $\mathrm{PCV}, \mathrm{RBC}$ and $\mathrm{Hb}$ respectively.

The results for Alanine aminotransferase ALT showed that fish fed $50 \%$ M. oleifera leaf meal diet had the highest value of $13.20 \mathrm{Ul}-1$ and least value of 20.48 Ul-1 was observed in fish fed control diet as shown in table 5 .

The Aspartate aminotransferase AST results obtained showed that fish fed $50 \%$ M. oleifera leaf meal diet recorded the highest value of $27.00 \mathrm{Ul}-1$ and was significantly $(\mathrm{p}<0.05)$ different from value of 25.00 Ul-1 jointly obtained for fish fed $30 \%$ and $40 \%$ M. oleifera leaf meal diet as shown in table 5 .

The Alkaline phosphatase ALP results showed that fish fed 50\% M. oleifera leaf meal diet recorded the highest value of $59.00 \mathrm{Ul}^{-1}$ and was significantly $(\mathrm{p}<0.05)$ from values obtained in fish fed $0 \%, 10 \%, 20 \%$, $30 \%$ and $40 \% \mathrm{M}$. oleifera leaf meal diet. The least value was recorded in fish fed control diet.

\section{Discussion}

The growth and nutrient utilization by fishes decreased as $M$. oleifera leaf meal increased in diets. This observation may be as a result of persistent increase in the substitution levels of fish meal with $M$. oleifera leaf meal in the diets which could retard growth as reported by Richter et al. and also supported by Afung et al. who reported that solvent extracted $M$. oleifera leaf meal could replace $30 \%$ of fish meal in the diets Oreochromis niloticus. The decrease in the growth rate could also be due to reduction in level of protein and essential amino acids in the diet having higher substitution levels of fish meal with M. oleifera leaf meal [30]. The result of the specific growth rate (SGR) could be due to differences in the M. oleifera leaf meal substitution levels which decreased considerably from $30 \%$ to $50 \%$ substitution levels in the diets. The consumption of antimetabolites contained in $M$. oleifera leaf meal based diets (phenol, tannins, phytate and saponins) are probably responsible for the retarded growth response in the fishes. Protein efficiency ratio (PER) was highest in fishes fed the control diet but did not show statistical significant difference ( $p>0.05)$ form fishes fed with 10 and $20 \%$ M. oleifera leaf meal diets. This result seems to have a link with palatability of the diets which caused reduced feed

\begin{tabular}{|c|c|c|c|c|c|c|c|}
\hline Parameters & Initial & A & B & C & D & $\mathbf{E}$ & $\mathbf{F}$ \\
\hline $\operatorname{ALT}\left(\mathrm{UL}^{-1}\right)$ & $11.30^{b} \pm 0.20$ & $11.30^{\mathrm{b}} \pm 0.30$ & $11.50^{b} \pm 0.50$ & $11.99^{b} \pm 1.00$ & $1290^{a} \pm 0.40$ & $13.00^{a} \pm 1.00$ & $13.20^{a} \pm 0.20$ \\
\hline AST $\left(U^{-1}\right)$ & $19.57^{c} \pm 0.12$ & $20.40^{c} \pm 0.20$ & $20.58^{c} \pm 0.20$ & $20.90^{c} \pm 1.50$ & $25.00^{b} \pm 1.00$ & $25.00^{b} \pm 2.50$ & $27.00^{\mathrm{a}} \pm 1.00$ \\
\hline $\operatorname{ALP}\left(\mathrm{UL}^{-1}\right)$ & $47.50^{d} \pm 5.00$ & $48.40^{d} \pm 2.00$ & $48.60^{d} \pm 3.50$ & $47.70^{d} \pm 1.00$ & $49.90^{c} \pm 2.60$ & $55.00^{b} \pm 5.00$ & $59.00^{a} \pm 2.00$ \\
\hline
\end{tabular}

Figures on the same row having the same superscript are not significantly different $(p>0.05)$

Table 5: Serum enzyme indices of Clarias gariepinus juvenile fed different levels of Moringa oleifera leaf meal diet. 
Citation: Ozovehe BN (2013) Growth Performance, Haematological Indices and Some Biochemical Enzymes of Juveniles Clarias gariepinus (Burchell 1822) Fed Varying Levels of Moringa oleifera Leaf Meal Diet. J Aquac Res Development 4:166 doi:10.4172/2155-9546.1000166

intake. The importance of feed intake by fishes as a determinant of its performance has been emphasized [31-33]. Fishes fed control diet, $10 \%$ and $20 \% \mathrm{M}$. oleifera leaf meal based diet showed better feed conversion ratio (FCR) in all the experimental diets. However, the decreasing trend as $M$. oleifera leaf meal increased in the diet as been reported in diets containing black gram seed meal [34] and diet with grass pea seed meal [35].

Haematological components of blood are valuable in monitoring feed toxicity especially with feed constituents that affect the formation of blood [36]. All the haematological parameters measured in this study were within the recommended physiological ranges reported for Clarias gariepinus. However, a decrease in the haematology of fishes at significant level $(\mathrm{p}<0.05)$ from fishes fed with $20 \%$ to $50 \% \mathrm{M}$. oleifera leaf meal diets could be as a result of the presence of higher concentration of antimetabolites in the diets. This observation is in support of the work of Adeyemo [37], Osuigwe et al. [38] and Sotolu and Faturoti who reported that the reduction in value of Packed Cell Volume (PCV), Haemoglobin ( $\mathrm{Hb}$ ) and Red Blood Cell (RBC) were due to the presence of toxic substances in the diet of fish. An increase in White Blood Cells (WBC) and lymphocyte count (lymph) is usually associated with microbial infection or the presence of foreign body or antigen in the circulating system [36]. The haematological results showed that the fishes fed with lower substitution levels of $M$. oleifera leaf meal diet had better health status than those of higher substitution levels.

There were significant increase $(\mathrm{p}<0.05)$ in the activities of serum enzymes (Aspartate aminotransferase AST, Alanine aminotransferase ALT and Alkaline phosphatase, ALP) as the level of M. oleifera leaf meal increased considerably from $20 \%$ in the diet. Elevated AST, ALT and ALP activities in fish fed 30\% M. oleifera leaf meal diet and above are suggestive of hepatic cellular damage leading to their leakage into circulation $[39,40]$.

In conclusion, the results obtained from this study showed that $M$. oleifera leaf meal could be substituted with fish meal up to $10 \%$ level in Clarias gariepinus diets without any negative effects on the growth and feed efficiency. The toxicological test also showed that $10 \%$ substitution rate of $M$. oleifera leaf meal in catfish (Clarias gariepinus) diet would not have any adverse effect on the blood and serum enzyme.

\section{References}

1. FAO (1997) Food and Agriculture Organization of the United Nations. Review of the State of World Aquaculture. FAO Fisheries Circular No. 886, Review 1, Rome, Italy.

2. Jones RJ (1979) The value of Leucaena leucocephala as a feed for ruminants in the tropics. World Anim Rev 31: 13-23.

3. Ter Muellen U, Glinther K D El-Harith EA (1981) Metabolic effects of mimosine on tyrosine in rat. Z Tierphysiol Tierenahrg Futtermittelkde 46: 264-269.

4. D' Mello JPF, Acamovic T (1989) Leucaena leucocephla in poultry nutrition-A review. Animal Feed Science and Technology 26: 1-28.

5. Hammond A (1995) Leucaena toxicosis and its control in ruminants. J Anim Sci 73: $1478-1492$

6. Ghosh M, Atreja P, Buragohain R, Banyopadhyay S (2007) Influence of shortterm Leucaena leucocephala feeding on milk yield and its composition, thyroid hormones, enzyme activity, and secretion of mimosine and its metabolites in milk cattle. Journal of Agricultural Science 145: 407-414.

7. Ng WK, Wee K L (1989) The nutritive value of cassava leaf meal in pelleted feed for Nile tilapia. Aquaculture 83: 45-58.

8. Yousif OM, Alhadhrami GA, Passaraki M (1994) Evaluation of dehydrated alfalfa and saltbush Altiplex leaves in diets for Tilapia (Oreochromis niloticus L.). Aquaculture 126: 341-347.
9. Reyes OS, Fermin AC (2003) Terrestrial leaf meals of freshwater aquatic fern as potential feed ingredients for farmed abalone Haliotis asinine (Linnaeus 1758). Aquaculture res 34: 593-599.

10. Woolfe JA (1992) Sweet potato an untapped food resource. Cambridge University Press, Cambridge, pp: 643.

11. Ali MA, Tageldin TH, Solaimon EM (1999) Effect of sweet potato tops or roots in growing rabbit diets on growing performance digestibility, carcass traits and Economic Efficiency. Egypt Rabbit Sci 9: 13-23.

12. Ishida H, Suzuno N, Sugiyama S, Imami T, Tadokoro T, et al. (2000) Nutritive value on chemical components of leaves, stalks and stem of sweet potato (Ipomoea batatas Poir). Food chem 68: 359-367.

13. Reyes sanchez N, Ledin S, Ledin I (2006a) Biomasss production and chemical composition of Moringa oleifera under different management regimes in Nicaragua. Agroforestry system 66: 231-242.

14. Manh L, Nguyen N, Ngoi T ( 2005) Introduction and evaluation of Moringa oleifera for biomass production and feed for goats in the Mekong delta Livestock Research for Rural Development 17: 9.

15. Ben Salem H, Makkar H (2009) Defatted Moringa oleifera seed meal as a feed additive for sheep. Animal Feed Science and Technology 150: 27-33.

16. Reyes-Sánchez N, Spörndly E, Ledin I (2006b) Effect of feeding different levels of foliage of Moringa oleifera to creole dairy cows on intake, digestibility, milk production and composition. Livestock Science 101: 24-31.

17. Richter N, Siddhruraju A, Becker K (2003) Evaluation of nutritional quality of moringa (Moringa oleifera Lam.) leaves as alternative protein source for Tilapia (Oreochromis niloticus L.). Aquaculture 217: 599-611.

18. Sawwatt SV, Kapange SS, Karkengi AMV (2002) The effects of intake, digestibility and growth of goats when sunflower seed cake is replaced with Moringa Oleifera Leaves Supplements fed with Chloris gayana hay. Agroforestry Systems 56: 241-247.

19. AOAC (2000) Association of Official Analytical Chemists international (AOAC) Official methods of analysis, $17^{\text {th }}$ edition AOAC International, Gaithersburg, MD, USA

20. Eyo AA (1994) The requirement for formulating standard artificial fish feed paper presented at the $11^{\text {th }}$ Annual Conference of the Fisheries Society of Nigeria (FiSON), held at the Lagos State Auditorium Secretariat Alausa Ikeja, Lagos State 40-70.

21. Okoye FC, Sule OD (2001) Agricultural by-products of arid-zone of Nigeria and their utilization in fish feed. Fish nutrition and fish feed technology in Nigeria. In: Eyo A.A., (eds) Proceedings of the First National Symposium of fish nutrition and fish feed technology NIOMR Lagos 8-13.

22. Bagenal TB (1978) Methods of assessment of fish production in fresh water Blackwell Science publication Oxford IBP. Handbook No. 3 pp 35.

23. APHA (1976) Standard methods for the examination of water and wastewater Am Public Health Assoc $14^{\text {th }}$ Ed. Washington D.C.

24. Klontz GW, Smith L S (1968) Method of using fish as biological research subjects. In: methods of animal experimentation volume iii (ed. W.I. Grey), 323383. Academic press, New York.

25. Wedemeyer GA, Yasutake WT (1977) Clinical methods for the assessment of the effects of environmental stress on fish health. United States Fish and Wildlife Service, Federal Government Series, Technical papers pp: 89.

26. Ogbu SI, Okechukwu FI (2001) The effects of storage temperature prior to separation on plasma and serum potassium. J Med Lab Sci 10: 1-4.

27. Wright PJ, Leathwood PD, Plummer DT (1972) Enzyme in rat urine: Alkaline phosphtase. Enzymologia 42: 317-327.

28. Reitman S, Frankel S (1957) A Colorimetric method for the determination of glutamic-ozaloacetic and glutamic-pyruvic transaminases. Am J Clin Pathol 28: 56-63.

29. Duncan DB (1955) Multiple range and multiple F tests. Biometrics 11: 1-42.

30. Russel LE, Cromwell GL, Stahly TS (1983) Tryptophan, threonine, isoleucine and methionine supplementationofcorn-soybean meal diet for growing pigs. J Animal Sci 56: 1115-1123.

31. Preston TR, Leng RA (1987) Matching production systems with available 
Citation: Ozovehe BN (2013) Growth Performance, Haematological Indices and Some Biochemical Enzymes of Juveniles Clarias gariepinus (Burchell 1822) Fed Varying Levels of Moringa oleifera Leaf Meal Diet. J Aquac Res Development 4:166 doi:10.4172/2155-9546.1000166

resources in the tropics and subtropics. Penambul Books Amidale, New South Wales, Australia; $127 \mathrm{pp}$

32. Faturoti EO (1989) Effects of supplementary feeding and organic manuring on the production of African catfish: Clarias gariepinus (Burchell 1822). J West Africa Fish 4: 187-195.

33. Pillay TVR (1990) Aquaculture principles and practices. Fishing News Books. A division of Blackwell Scientific Publications Ltd. 575 pp.

34. Ramachandran S, Ray AK (2007) Nutritional evaluation of fermented black gram (Phaseolus mungo) seed meal in compound diets for rohu labeo rohita (Hamilton), fingerlings. J Appl Ichthyol 23: 74-79.

35. Ramachandran S, Ray AK (2004) Inclusion of extruded grass pea, Lathyrus sativus seed meal in compounded diets rohu, Labeo rohita (Hamilton 1822), fingelings. J Appl Ichthyyol 34: 205-218.
36. Oyawoye EO, Ogunkunle M (1998) Physiological and biochemical effects of raw jack beans on broilers. Proceedings of annual Conference of Nigerian Society of Animal production 23: 141-142.

37. Adeyemo OK (2005) Haematological and histopathological effects of cassava mill effluent in Clarias gariepinus. Afr J of Biomed Res 8: 179-183.

38. Osuigwe DI, Obiekezie Al Onuoha GC (2005) Some haematological changes in hybrid catfish (Heterobranchus longifilis x Clarias gariepinus) fed differen dietry levels of raw and boiled jackbean (Canavalia ensiformis) seedmeal. Afri J Biotech 4: 1017-1021.

39. Molander DW Sheppard E, Payne MA (1957) Serum transaminase in liver disease. J Am Med Assoc 163: 1461-1465.

40. Mousa MMA, El-Ashram AMM, Hamed M (2008) Effects of Neem leaf extract on freshwater fishes and zooplankton community. The central laboratory for Aquaculture Research, Cairo, Egypt, 12-14. 